\title{
Lipid metabolism in shorn and unshorn pregnant sheep
}

\author{
BY M. E. SYMONDS ${ }^{1 *}$, M. J. BRYANT ${ }^{2}$ AND M. A. LOMAX ${ }^{1}$ \\ Departments of ${ }^{1}$ Physiology and Biochemistry and ${ }^{2}$ Agriculture, University of Reading, \\ Whiteknights, Reading RG6 $2 A J$
}

(Received 26 August 1988 - Accepted 26 January 1989)

\begin{abstract}
The aim of the present study was to determine how the long-term metabolic adaptations to winter shearing of the pregnant ewe result in significant changes in the rates of lipid mobilization and utilization of non-esterified fatty acids (NEFA) in comparison with unshorn controls. Continuous infusions of $\left[1-{ }^{14} \mathrm{C}\right.$ |palmitic acid, $\left|2-{ }^{3} \mathrm{H}\right|$ glycerol and $\mathrm{NaH}^{14} \mathrm{CO}_{3}$ were used to measure whole-body lipid metabolism in fed (estimated metabolizable energy (ME) intake $9.54 \mathrm{MJ} / \mathrm{d}$ ) and under-fed (estimated ME intake of $3 \mathrm{MJ} / \mathrm{d}$ ), shorn and unshorn sheep over the final 4 weeks of pregnancy. Whole-body carbon dioxide, estimated heat production, total NEFA entry and oxidation rates were all significantly higher in fed shorn ewes compared with unshorn controls, even though there was no difference in the arterial plasma NEFA concentration. These differences may be mediated via an increase in the plasma concentrations of thyroid hormones in shorn animals. As a result of under-feeding any significant differences in lipid metabolism between shorn and unshorn groups were removed. In all sheep the mean total NEFA entry rate as measured using $\left[1-{ }^{14} \mathrm{C}\right]$ palmitic acid was 3.4 times the value obtained using $\left[2-{ }^{3} \mathrm{H}\right]$ glycerol. It is concluded that when sheep are fed on a diet from which no more than half the required ME for late pregnancy is obtained, then lipolysis of body fat depots occurs via the incomplete breakdown of adipose tissue triglycerides. This effect is significantly greater in the fed shorn pregnant ewe which exhibits higher entry and oxidation rates of NEFA.
\end{abstract}

Lipid metabolism: Pregnancy : Shearing: Undernutrition: Sheep.

The practice of winter shearing pregnant ewes 8 weeks before lambing results in a chronic increase in whole-body energy requirements which is met by the oxidation of body fat depots (Symonds et al. 1986a). However, the increase in nutrient requirements necessary to support the rapid rate of fetal growth over the final 2 weeks of pregnancy can cause a metabolic imbalance, resulting in pregnancy toxaemia and concomitant hypoglycaemia and hyperketonaemia (Lindsay \& Pethick, 1983). These symptoms have been observed in unshorn but not shorn ewes when both groups were consuming a similar quantity of metabolizable energy (ME) and all animals were carrying multiple pregnancies (Symonds et al. 1988 a). We have, therefore, suggested that in the shorn ewe metabolic adaptations to long-term cold exposure occur which improve the ewe's ability to utilize body fat as an energy source and maintain the supply of glucose to the fetus (Symonds et al. 1988a). This latter effect is likely to be caused by the significantly higher whole-body glucose entry rate recorded in shorn animals compared with unshorn controls (Symonds et al. 1988 b). These studies have indicated that despite an increased energy expenditure during late pregnancy the shorn ewe may be better adapted to utilize non-esterified fatty acids (NEFA) as an energy source and remain normoglycaemic without exhibiting high plasma NEFA and ketone body concentrations. This is in contrast to the effect of starving unshorn ewes for 3-4 d, when the higher entry and oxidation rates of both individual and total NEFA are directly related to an increase in the plasma NEFA concentration (Pethick et al. 1983). The

* Present address: Department of Applied Biochemistry and Food Science, University of Nottingham School of Agriculture, Sutton Bonington, Loughborough LE12 5RD. 
aim of the present study was, therefore, to determine if long-term metabolic adaptations to continuous cold exposure may benefit the shorn pregnant ewe by causing a significant change in the relation between the plasma concentration and oxidation rate of NEFA.

This study involved the measurement of whole-body entry and oxidation rates of total NEFA using $\left[1-{ }^{14} \mathrm{C}\right]$ palmitic acid, $\left[2-{ }^{3} \mathrm{H}\right]$ glycerol and $\mathrm{NaH}^{14} \mathrm{CO}_{3}$ in fed and under-fed, shorn and unshorn pregnant ewes over the final 4 weeks of pregnancy. In addition, measurements of circulating hormone levels were made in order to assess the role of growth hormone $(G H)$, insulin, glucagon, cortisol, thyroxine $\left(T_{4}\right)$ and triidothyronine $\left(T_{3}\right)$ in the hormonal regulation of lipid metabolism in the pregnant ewe.

\section{MATERIALS AND METHODS}

\section{Animals and diets}

Twelve pregnant Bluefaced Leicester $\times$ Swaledale ewes, diagnosed as being twin pregnant by either X-ray (Institute of Grassland and Animal Production, Hurley, Berks) or a realtime ultrasound echograph, were paired with respect to body-weight (range 70-92 kg). Ewes were housed individually at ambient temperature and at 8 weeks before lambing one ewe from each pair was shorn. All ewes were fed on a diet identical to that described by Symonds et al. (1986a) which comprised barley concentrate $(\mathrm{g} / \mathrm{kg}$ fresh weight: 940 barley, 30 urea, 30 vitamins and minerals) and chopped ammonia-treated straw in proportions $1: 3$ on a dry-weight basis. The diet was given by automatic feeders in hourly portions and the refusals were weighed at 08.30 hours. The mean estimated ME intakes over the experimental period for shorn and unshorn groups were 9.78 (SD 1.36) and 9.30 (SD 1.72) $\mathrm{MJ} / \mathrm{d}$ respectively, and the mean nitrogen intakes were $22 \cdot 3$ (SD $2 \cdot 1$ ) $\mathrm{g} / \mathrm{d}$ in the shorn group and $20 \cdot 1$ (SD 3.2) $\mathrm{g} / \mathrm{d}$ for the unshorn group. These values were calculated from the measured fresh weight intakes of barley concentrate and chopped ammonia-treated straw as described by Symonds et al. (1988 a). In the studies involving the effect of under-feeding, the pregnant ewes were given $0.5 \mathrm{~kg}$ chopped ammonia-treated straw at 17.00 hours for 4 $\mathrm{d}$ to give an estimated $\mathrm{ME}$ intake of $3 \mathrm{MJ} / \mathrm{d}$. Experiments were performed initially on two pairs of animals, when the mean minimum and maximum daily temperatures recorded at 09.00 hours were $8.0(\mathrm{SD} 4.3)^{\circ}$ and $10.1(\mathrm{SD} 3.8)^{\circ}$ respectively, and then on the remaining four pairs when the mean minimum and maximum temperatures were 1.7 (SD 2.0$)^{\circ}$ and $4 \cdot 3(\operatorname{SD} 2 \cdot 4)^{\circ}$ respectively.

All ewes produced live fetuses which were delivered by Caesarian section on day 144 (SEM 1) of pregnancy. Four pairs of animals produced twins and one pair bore single lambs, in the remaining pair the unshorn ewe had twins and the shorn ewe a single lamb. There was no significant difference in lamb birth weight (shorn 4.55 (SEM $0 \cdot 34$ ) $\mathrm{kg}, n 10$; unshorn $4 \cdot 11$ (SEM $0 \cdot 15) \mathrm{kg}, n 11$ ).

\section{Experimental design}

All ewes were surgically prepared with carotid artery catheters as described by Symonds $e t$ al. $(1988 b)$. The operations were performed on ewes carrying fetuses aged between 97 and $127 \mathrm{~d}$, estimated from known mating dates. All ewes were allowed at least a $7 \mathrm{~d}$ period to recover from surgery before any measurements were made. All catheters had fresh sterile heparinized saline ( $9 \mathrm{~g}$ sodium chloride/1) added daily ( 250 units heparin $/ \mathrm{ml})$ : care was taken to remove the old saline and sufficient heparinized saline was then added into the catheter, without injecting heparin into the animal's circulation. The schedule of experimentation on all pairs of animals is summarized in Table 1. In the studies involving under-feeding, measurements of NEFA kinetics were made on the 3rd day of this dietary regimen. 
Table 1. Schedule of experiments on pairs of shorn and unshorn pregnant ewes

\begin{tabular}{|c|c|c|c|c|c|c|}
\hline \multirow[b]{2}{*}{$\begin{array}{l}\text { Pair no...... } \\
\text { Experimental protocol }\end{array}$} & \multicolumn{6}{|c|}{ Stage of pregnancy* (d) } \\
\hline & 1 & 2 & 3 & 4 & 5 & 6 \\
\hline Operation & 97 & 106 & 116 & 116 & 127 & 118 \\
\hline NEFA kinetics; fed & 119 & $125 \dagger$ & 127 & 133 & 141 & 131 \\
\hline $\mathrm{NaH}^{14} \mathrm{CO}_{3}$ infusion, fed & 122 & $132 \dagger$ & 131 & 135 & 143 & 134 \\
\hline NEFA kinetics, under-fed & 129 & - & 134 & 138 & $145 \ddagger$ & 138 \\
\hline $\mathrm{NaH}^{14} \mathrm{CO}_{3}$ infusion, under-fed & 131 & - & 136 & 140 & - & 140 \\
\hline
\end{tabular}

NEFA, non-esterified fatty acids.

* Estimated from known mating date.

$\dagger$ Experiment only performed on shorn ewe.

$\ddagger$ Experiment only performed on unshorn ewe.

\section{Experimental procedures}

At least $2 \mathrm{~d}$ before measurements were made the jugular vein was catheterized to enable infusion of the isotopes. The infusion solution was prepared by adding $\left[1-{ }^{14} \mathrm{C}\right]$ palmitic acid (New England Nuclear) to freshly prepared plasma as described by Bell \& Thompson (1979), which was then added to sterile saline via a millipore filter together with [2${ }^{3} \mathrm{H}$ ]glycerol (New England Nuclear). At approximately 09.00 hours a constant intravenous infusion of $0.21 \mu \mathrm{Ci}\left[1-{ }^{14} \mathrm{C}\right]$ palmitic acid/min plus $0.94 \mu \mathrm{Ci}\left[2-{ }^{3} \mathrm{H}\right]$ glycerol $/ \mathrm{min}$ in sterile saline was started and maintained for $6 \mathrm{~h}$ using a peristaltic pump (Gilson 2 Minipulse 2; Gilson, Anachem House, 20 Charles Street, Luton, Beds LU2 OEB), with samples from which the infusion rate was measured being taken at the end of each infusion period. This procedure produced a constant specific radioactivity (SRA) of plasma NEFA and glycerol for the final $1.5 \mathrm{~h}$ of the infusion (Tables 2 and 3, pp. 39 and 40). During the final $1.5 \mathrm{~h}$ of isotope infusion, four sets of $30 \mathrm{ml}$ blood samples were taken from the carotid artery into heparinized syringes and then immediately placed in ice-cold test-tubes. The plasma was then collected and stored at $-20^{\circ}$. Aprotinin (250 Kallikrein-inactivating units; Sigma Chemical Co., Poole, Dorset) was also added to $1 \mathrm{ml}$ blood which was used for analysis of plasma glucagon. Blood for the measurement of the SRA of carbon dioxide and determination of blood gases and packed cell volume (PCV) was taken as described by Symonds et al. $(1988 \mathrm{~b})$. The sampling times were approximately $13.30,14.00,14.30$ and 15.00 hours.

At least $2 \mathrm{~d}$ after the infusion of radio-labelled NEFA, whole-body $\mathrm{CO}_{2}$ entry rate was determined by a similar method to that described by Symonds et al. $(1988 \mathrm{~b})$, with the modification that the infusion $\left(0.14 \mu \mathrm{Ci} /\right.$ min plus carrier $\left.\mathrm{NaHCO}_{3}(1 \mathrm{~g} / 1)\right)$ was commenced at approximately 19.00 hours and the arterial sampling times were $08.30,09.00,09.30$ and 10.00 hours on the next day. The SRA of blood $\mathrm{CO}_{2}$ was observed to be constant during the sampling period (Tables 2 and 3 ).

\section{Laboratory procedures}

The concentrations of glucose, lactate, $\mathrm{D}(-)-3$-hydroxybutyrate, $\mathrm{GH}$, insulin, glucagon, cortisol, $\mathrm{T}_{4}$ and $\mathrm{T}_{3}$ in plasma, the concentrations of blood gases, SRA of $\mathrm{CO}_{2}, \mathrm{PCV}$ and the molar ratios of the plasma concentrations insulin:glucagon (I:G) and insulin:growth hormone (I:GH) were all measured using methods identical to those described by Symonds et al. $(1986 a, 1988 a, b)$. The only modification was that the concentration of blood 
haemoglobin was measured via the cyanmethaemoglobin method using the Boehringer Mannheim test kit (no. 124 7429).

The radioactivity of NEFA in plasma was determined using the method described by Pethick et al. (1983) with the modification that $2 \mathrm{ml}$ plasma were used together with double the volume of all reagents described by Pethick et al. (1983). The final pooled heptane extract was evaporated to dryness using a freeze-dryer. The NEFA was then dissolved in $0 \cdot 1 \mathrm{ml}$ heptane and the ${ }^{14} \mathrm{C}$-labelled NEFA measured in $5 \mathrm{ml}$ liquid scintillant (Cocktail T; BDH Chemicals, Poole, Dorset) using a Packard liquid-scintillation counter (Tri-Carb 460 CD). Recovery of $1{ }^{14} \mathrm{C}$-labelled NEFA added to plasma was 98.7 (SEM 1.7) \% $(n 6)$ and the intra-assay coefficient of variation $(\mathrm{CV})$ was $3.0 \%(n 5)$. Total plasma NEFA was determined as described by Symonds et al. (1986a) and SRA expressed as disintegrations/min (dpm) $\left[{ }^{14} \mathrm{C}\right]$ palmitic acid per mmol total NEFA.

Plasma for the determination of the SRA of glycerol was deproteinized with the addition of an equal volume of $6 \%$ perchloric acid within $2 \mathrm{~h}$ of taking the blood sample. The supernatant fraction was then collected after centrifugation and neutralized with $2 \mathrm{M}$ potassium hydroxide and then stored at $-20^{\circ}$ until analysed (Bergman, 1968). The SRA of glycerol was determined by the passage of $2 \mathrm{ml}$ deproteinized extracts through successive ion-exchange resins, as described by Symonds et al. $(1988 b)$ for glucose, with the addition of a Dowex 1 (borate form, 200400 mesh) resin in order to trap any labelled glucose (Hammerstedt, 1973). The eluate and washings (total volume $8 \mathrm{ml}$ ) were collected in scintillation vials, frozen and tritiated water removed by freeze-drying. The $\left[{ }^{3} \mathrm{H}\right]$ glycerol was then measured in $5 \mathrm{ml}$ liquid scintillant as described previously for $\left[{ }^{14} \mathrm{C}\right] \mathrm{NEFA}$. Recovery of $\left[2{ }^{3} \mathrm{H}\right]$ glycerol was $96 \cdot 6$ (SEM 0.6$) \%(n 6)$ and the intra-assay CV was $2 \cdot 0 \%(n$ 5). The recovery of $\left[\mathrm{U}^{14} \mathrm{C}\right] \mathrm{glucose}$ added to the same sample was less than $0 \cdot 1 \%$. It is also unlikely that any $\left[2-{ }^{3} \mathrm{H}\right]$ glycerol would be incorporated into glucose during the infusion period, because this $\mathrm{H}$ atom is lost in the conversion of glycerol-3-phosphate to dihydroxyacetone phosphate before entering the glycolytic pathway. The concentration of glycerol in plasma was measured using the same neutralized perchloric acid extracts with the enzymes glycerokinase $(E C 2.7 .1 .30)$ and NAD-dependent glycerophosphate dehydrogenase (EC 1.1.1.8) as described by Wieland (1974). The intra- and interassay CV were $2 \cdot 0(n 5)$ and $7.9 \%(n 9)$ respectively.

\section{Calculations}

NEFA entry rate $\left(\mathrm{ER}_{\mathrm{NEFA}}\right)(\mathrm{mmol} / \mathrm{min})=\mathrm{I} / \mathrm{NEFA}$ SRA,

where $I$ is the infusion rate of $\left[1{ }^{14} \mathrm{C}\right]$ palmitic acid $(\mathrm{dpm} / \mathrm{min})$ and SRA is the specific activity of total NEFA $(\mathrm{dpm} / \mathrm{mmol})$ in arterial plasma at equilibrium.

Glycerol entry rate $\left(\mathrm{ER}_{\mathrm{G}}\right)(\mathrm{mmol} / \mathrm{min})=\mathrm{I} /$ glycerol SRA,

where $\mathrm{I}$ is the infusion rate of $\left[2{ }^{3} \mathrm{H}\right] \mathrm{glycerol}(\mathrm{dpm} / \mathrm{min})$ and SRA is the specific activity of glycerol $(\mathrm{dpm} / \mathrm{mmol})$ in arterial plasma at equilibrium.

Apparent rate of incomplete breakdown of adipose tissue triglycerides $=$

$$
\mathrm{ER}_{\mathrm{NEHA}}-\left(3 \times \mathrm{ER}_{\mathrm{G}}\right) \text {, }
$$

which assumes the release of $1 \mathrm{~mol}$ glycerol to 3 mol NEFA.

The proportion of blood $\mathrm{CO}_{2}$ derived from NEFA (transfer quotient; TQ) = plateau arterial $\mathrm{CO}_{2} \mathrm{SRA} /$ plateau arterial NEFA SRA, during $\left[1-{ }^{14} \mathrm{C}\right]$ palmitic acid infusion, where SRA is expressed as ${ }^{14} \mathrm{C} \mathrm{dpm} / \mathrm{mAtom} \mathrm{C}$ at equilibrium.

$$
\mathrm{CO}_{2} \text { entry rate }\left(\mathrm{ER}_{\mathrm{CO}_{2}}\right)(\mathrm{mmol} / \mathrm{min})=\mathrm{I} / \mathrm{CO}_{2} \mathrm{SRA} \text {, }
$$


Table 2. Regression analysis of changes in the values of arterial non-esterified fatty acids $(N E F A)$, carbon dioxide and glycerol specific radioactivities $(S R A)$ during sampling in fed shorn $(S)$ (n 6) and unshorn (US) (n 5) pregnant ewes*

\begin{tabular}{|c|c|c|c|c|c|c|}
\hline Infusate & Measurement $\dagger$ & & Mean & SEM & $\begin{array}{c}\text { Slope of } \\
\text { regression } \\
\text { line } \\
\text { (change } / 0.5 \mathrm{~h} \text { ) }\end{array}$ & $\begin{array}{c}\text { Change } \\
\text { during } \\
\text { sampling } \\
\text { period } \neq(\%)\end{array}$ \\
\hline$\left[1-{ }^{14} \mathrm{C}\right]$ palmitic acid & $\begin{array}{l}\text { NEFA SRA } \\
(\mathrm{dpm} / \mathrm{mmol}) \\
\mathrm{CO}_{2} \text { SRA } \\
(\mathrm{dpm} / \mathrm{mmol}) \\
\mathrm{NEFA}(\mathrm{mm}) \\
\mathrm{CO}_{2}(\mathrm{mM})\end{array}$ & $\begin{array}{l}\text { S } \\
\text { US } \\
\text { S } \\
\text { US } \\
\text { S } \\
\text { US } \\
\text { S } \\
\text { US }\end{array}$ & $\begin{array}{c}101 \\
169 \\
4 \cdot 1 \\
3 \cdot 9 \\
0 \cdot 78 \\
0 \cdot 86 \\
26 \cdot 48 \\
24.49\end{array}$ & $\begin{array}{l}1 \\
4 \\
0 \cdot 1 \\
0 \cdot 2 \\
0 \cdot 08 \\
0 \cdot 02 \\
0 \cdot 11 \\
0 \cdot 11\end{array}$ & $\begin{array}{r}-0.72 \\
0.44 \\
0.67 \\
0.17 \\
-0.72 \\
0.44 \\
0.74 \\
0.81\end{array}$ & $\begin{array}{l}0 \cdot 5 \\
4 \cdot 1 \\
6 \cdot 6 \\
6 \cdot 3 \\
0 \cdot 5 \\
4 \cdot 1 \\
1 \cdot 1 \\
0 \cdot 8\end{array}$ \\
\hline$\left[2-{ }^{3} \mathrm{H}\right]$ glycerol & $\begin{array}{r}\text { Glycerol SRA } \\
(\mathrm{dpm} / \mathrm{mmol}) \\
\text { Glycerol (mM) }\end{array}$ & $\begin{array}{l}\text { S } \\
\text { US } \\
\text { S } \\
\text { US }\end{array}$ & $\begin{array}{l}5666 \\
8949 \\
0.164 \\
0.148\end{array}$ & $\begin{array}{l}166 \\
281 \\
0.003 \\
0.006\end{array}$ & $\begin{array}{r}0.72 \\
0.78 \\
-0.07 \\
-0.79\end{array}$ & $\begin{array}{r}6 \cdot 3 \\
7 \cdot 6 \\
6 \cdot 8 \\
-3 \cdot 1\end{array}$ \\
\hline $\mathrm{NaH}^{14} \mathrm{CO}_{3}$ & $\begin{array}{l}\mathrm{CO}_{2} \text { SRA } \\
(\mathrm{dpm} / \mathrm{mmol}) \\
\mathrm{CO}_{2}(\mathrm{~mm})\end{array}$ & $\begin{array}{l}\text { S } \\
\text { US } \\
\text { S } \\
\text { US }\end{array}$ & $\begin{array}{l}11 \cdot 3 \\
17 \cdot 8 \\
26 \cdot 29 \\
23 \cdot 45\end{array}$ & $\begin{array}{l}0 \cdot 1 \\
0 \cdot 2 \\
0 \cdot 17 \\
0 \cdot 04\end{array}$ & $\begin{array}{r}0.89 \\
0.38 \\
-0.24 \\
-0.14\end{array}$ & $\begin{array}{l}0.7 \\
0.3 \\
0.5 \\
0.9\end{array}$ \\
\hline
\end{tabular}

dpm, Disintegrations/min.

* For details of dietary regimen, see p. 36.

+ For details of procedures, see p. 37.

$\ddagger$ No statistically significant changes with sampling time.

where $I$ is the infusion rate of $\mathrm{NaH}^{14} \mathrm{CO}_{3}(\mathrm{dpm} / \mathrm{min})$ and SRA is the specific activity of ${ }^{14} \mathrm{CO}_{2}(\mathrm{dpm} / \mathrm{mmol})$ in arterial blood at equilibrium.

Proportion of NEFA entry rate oxidized $=\left(\mathrm{TQ} \times \mathrm{ER}_{\mathrm{CO}_{2}}\right) / \mathrm{ER}_{\mathrm{NEFA}}$, where both $\mathrm{ER}_{\mathrm{CO}_{2}}$ and $\mathrm{ER}_{\mathrm{NEFA}}$ are expressed as mAtom C.

$\mathrm{NEFA}$ oxidation rate $(\mathrm{mmol} / \mathrm{min})=\mathrm{TQ} \times \mathrm{ER}_{\mathrm{CO}_{2}}$.

Total heat production $(H)$ was estimated from the measured $\mathrm{ER}_{\mathrm{CO}_{2}}$ as described by Symonds et al. $(1988 \mathrm{~b})$ and $H$ due to NEFA oxidation $(\mathrm{MJ} / \mathrm{d})$ was calculated by multiplying the NEFA oxidation rate (mol/d) by 11.3 (the energy content of 1 mol NEFA).

\section{Statistical analysis}

Comparison of values between fed, under-fed, shorn and unshorn groups

Statistical analysis of the whole-body entry rate and plasma concentrations of metabolites and hormones in the fed and under-fed ewes was performed using a Student's paired $t$ test (shorn $v$. unshorn). Significant changes within each group of animals with respect to the effects of under-feeding were also assessed by a Student's paired $t$ test.

Analysis of changes in values of measurements with time during sampling

Regression analyses were carried out for each group of sampling values obtained in fed, under-fed, shorn and unshorn animals, to calculate the mean percentage change with time over the $1.5 \mathrm{~h}$ sampling period. 
Table 3. Regression analysis of changes in the values of arterial non-esterified fatty acids $(N E F A)$, carbon dioxide and glycerol specific radioactivities $(S R A)$ during sampling in underfed shorn (S) (n 4) and unshorn (US) (n 4) pregnant ewes*

\begin{tabular}{|c|c|c|c|c|c|c|}
\hline Infusate & Measurement $\dagger$ & & Mean & SEM & $\begin{array}{c}\text { Slope of } \\
\text { regression } \\
\text { line } \\
\text { (change } / 0.5 \mathrm{~h} \text { ) }\end{array}$ & $\begin{array}{c}\text { Change } \\
\text { during } \\
\text { sampling } \\
\text { period } \ddagger(\%)\end{array}$ \\
\hline$\left[1{ }^{14} \mathrm{C}\right]$ palmitic acid & $\begin{array}{l}\text { NEFA SRA } \\
(\mathrm{dpm} / \mathrm{mmol}) \\
\mathrm{CO}_{2} \mathrm{SRA} \\
(\mathrm{dpm} / \mathrm{mmol}) \\
\mathrm{NEFA}(\mathrm{mm}) \\
\mathrm{CO}_{2}(\mathrm{~mm})\end{array}$ & $\begin{array}{l}\text { S } \\
\text { US } \\
\text { S } \\
\text { US } \\
\text { S } \\
\text { US } \\
\text { S } \\
\text { US }\end{array}$ & $\begin{array}{c}150 \\
188 \\
4 \cdot 0 \\
7 \cdot 4 \\
1 \cdot 43 \\
1 \cdot 60 \\
26 \cdot 83 \\
24 \cdot 88\end{array}$ & $\begin{array}{l}4 \\
5 \\
0.2 \\
0.4 \\
0.02 \\
0.02 \\
0.15 \\
0.17\end{array}$ & $\begin{array}{r}-0.18 \\
0.65 \\
0.77 \\
0.69 \\
-0.46 \\
0.86 \\
0.04 \\
0\end{array}$ & $\begin{array}{l}5.1 \\
5 \cdot 3 \\
4 \cdot 2 \\
6 \cdot 5 \\
0.7 \\
4 \cdot 0 \\
1 \cdot 0 \\
0.5\end{array}$ \\
\hline$\left[2-{ }^{3} \mathrm{H}\right]$ glycerol & $\begin{array}{r}\text { Glycerol SRA } \\
(\mathrm{dpm} / \mathrm{mmol}) \\
\text { Glycerol (mM) }\end{array}$ & $\begin{array}{l}\text { S } \\
\text { US } \\
\text { S } \\
\text { US }\end{array}$ & $\begin{array}{r}4252 \\
6427 \\
0 \cdot 220 \\
0 \cdot 190\end{array}$ & $\begin{array}{l}200 \\
263 \\
0.008 \\
0.004\end{array}$ & $\begin{array}{r}-0.40 \\
0.40 \\
-0.65 \\
-0.28\end{array}$ & $\begin{array}{r}1 \cdot 9 \\
9 \cdot 2 \\
-2 \cdot 5 \\
3 \cdot 2\end{array}$ \\
\hline $\mathrm{NaH}^{14} \mathrm{CO}_{3}$ & $\begin{array}{l}\mathrm{CO}_{2} \text { SRA } \\
(\mathrm{dpm} / \mathrm{mmol}) \\
\mathrm{CO}_{2}(\mathrm{~mm})\end{array}$ & $\begin{array}{l}\text { S } \\
\text { US } \S \\
\text { S } \\
\text { US§ }\end{array}$ & $\begin{array}{l}17 \cdot 1 \\
23 \cdot 3 \\
27 \cdot 57 \\
23 \cdot 04\end{array}$ & $\begin{array}{l}0 \cdot 3 \\
0 \cdot 3 \\
0 \cdot 24 \\
0 \cdot 23\end{array}$ & $\begin{array}{r}0.59 \\
0.56 \\
0.97 \\
-0.39\end{array}$ & $\begin{array}{l}2 \cdot 5 \\
3 \cdot 8 \\
1.5 \\
1 \cdot 4\end{array}$ \\
\hline
\end{tabular}

Table 4. Non-esterified fatty acids (NEFA) and glycerol metabolism in fed and under-fed shorn $(S)$ and unshorn (US) pregnant ewest

\begin{tabular}{|c|c|c|c|c|c|c|c|c|}
\hline & \multicolumn{3}{|c|}{ Fed } & \multicolumn{3}{|c|}{ Under-fed } & \multirow[b]{2}{*}{$\operatorname{SED}^{3}$} & \multirow[b]{2}{*}{$\mathrm{SED}^{4}$} \\
\hline & $\underset{\text { Mean }}{S}$ & $\begin{array}{c}\text { US } \\
\text { Mean }\end{array}$ & $\mathrm{SED}^{1}$ & $\begin{array}{c}S \\
\text { Mean }\end{array}$ & $\begin{array}{c}\text { US } \\
\text { Mean }\end{array}$ & $\mathrm{SED}^{2}$ & & \\
\hline Glycerol entry rate (mmol/min) & $0 \cdot 38$ & $0 \cdot 27$ & 0.07 & $0 \cdot 36$ & $0 \cdot 40$ & $0 \cdot 11$ & $0 \cdot 04$ & $0 \cdot 05$ \\
\hline \multicolumn{9}{|l|}{ NEFA entry rate using } \\
\hline$\left[1-^{14} \mathrm{C}\right] \mathrm{palmitic}$ acid (mmol/min) & $3-80^{*}$ & $2 \cdot 68$ & $0 \cdot 35$ & $4 \cdot 22$ & $4 \cdot 02$ & 0.96 & $0 \cdot 64$ & $1 \cdot 20$ \\
\hline$\left[2-{ }^{3} \mathrm{H}\right]$ glycerol $(\mathrm{mmol} / \mathrm{min}) \ddagger$ & $1 \cdot 14$ & 0.81 & $0 \cdot 21$ & 1.07 & $1 \cdot 18$ & $0 \cdot 36$ & $0 \cdot 13$ & $0 \cdot 15$ \\
\hline Incomplete breakdown $(\mathrm{mmol} / \mathrm{min}) \S$ & $2 \cdot 69^{*}$ & 1.87 & 0.42 & $3 \cdot 14$ & $2 \cdot 84$ & 0.63 & $1 \cdot 14$ & 0.52 \\
\hline Contribution to carbon dioxide output (\%) & 48 & 38 & 6 & 66 & 57 & 8 & I7 & 12 \\
\hline Proportion of entry rate oxidized & $0 \cdot 21$ & $0 \cdot 19$ & 0.09 & $0 \cdot 18$ & $0 \cdot 14$ & $0 \cdot 12$ & $0 \cdot 25$ & $0 \cdot 11$ \\
\hline Oxidation rate $(\mathrm{mmol} / \mathrm{min})$ & $0 \cdot 76^{*}$ & $0 \cdot 48$ & $0 \cdot 09$ & $0 \cdot 76$ & 0.53 & $0 \cdot 17$ & $0 \cdot 25$ & $0 \cdot 14$ \\
\hline
\end{tabular}

SED, standard error of difference; $\operatorname{SED}^{1}, \mathbf{S} v$. US, fed, $n 5 ; \operatorname{SED}^{2}, \mathrm{~S} v$. US, under-fed, $n 4 ; \operatorname{SED}^{3}$, fed $v$. under-fed, $\mathrm{S}, n 4 ; \mathrm{SED}^{4}$, fed $v$. under-fed, US, $n 5$.

Significant differences between means (S $v$. US) assessed by a paired $t$ test : ${ }^{*} P<0 \cdot 05$.

$\dagger$ For details of dietary regimen, see p. 36.

\$ Total NEFA entry rate calculated from $\left[2{ }^{3} \mathrm{H}\right]$ glycerol entry rate assumes the release of 1 mol glycerol to 3 mol NEFA. For details of calculations see p. 38.

$\S$ The difference between the NEFA and glycerol entry rates is equal to the apparent rate of incomplete breakdown of adipose tissue triglycerides. 
Table 5. Carbon dioxide entry rate $\left(E R_{\mathrm{Co}_{2}}\right)$, estimated whole-body heat production $(\mathrm{H})$ and estimated whole-body heat production due to NEFA oxidation $(\mathrm{H}-N E F A)$ of fed and under-fed shorn $(S)$ and unshorn (US) pregnant ewes $\dagger$

\begin{tabular}{|c|c|c|c|c|c|c|c|c|}
\hline & \multicolumn{3}{|c|}{ Fed } & \multicolumn{3}{|c|}{ Under-fed } & \multirow[b]{2}{*}{$\mathrm{SED}^{3}$} & \multirow[b]{2}{*}{$\operatorname{SED}^{4}$} \\
\hline & $\stackrel{S}{\text { Mean }}$ & $\begin{array}{c}\text { US } \\
\text { Mean }\end{array}$ & $\operatorname{SED}^{1}$ & $\underset{\text { Mean }}{S}$ & $\begin{array}{c}\text { US } \\
\text { Mean }\end{array}$ & $\operatorname{SED}^{2}$ & & \\
\hline $\mathrm{ER}_{\mathrm{CO}_{2}}(\mathrm{mmol} / \mathrm{min})$ & $25 \cdot 22^{\mathrm{a} *}$ & 20.82 & 0.80 & $18 \cdot 87^{\mathrm{b}}$ & 14.47 & $2 \cdot 40$ & 1.00 & 1.90 \\
\hline$H \notin(\mathrm{MJ} / \mathrm{d})$ & $20 \cdot 12^{\mathrm{a} *}$ & $16 \cdot 48$ & 0.69 & $14 \cdot 86^{\mathrm{b}}$ & $11 \cdot 20$ & 2.01 & 0.82 & 1.54 \\
\hline$H$-NEFA $\ddagger(\mathrm{MJ} / \mathrm{d})$ & $12 \cdot 25^{*}$ & 7.76 & $1 \cdot 43$ & $12 \cdot 24$ & 8.43 & $2 \cdot 13$ & $4 \cdot 13$ & 1.49 \\
\hline
\end{tabular}

SED, standard error of difference; $\operatorname{SED}^{1}, \mathrm{~S} v$. US, fed, $n 5 ; \operatorname{SED}^{2}, \mathrm{~S} v$. US, under-fed, $n 3 ; \operatorname{SED}^{3}$, fed $v$. under-fed, $\mathrm{S}, n 4 ; \mathrm{SED}^{4}$, fed $v$. under-fed, US, $n 3$.

a,b Values in the same rows with different superscript letters were significantly different, as assessed by a paired $t$ test (fed $v$. under-fed): $P<0.05$.

Significant differences between means (S $v$. US), assessed by a paired $t$ test: ${ }^{*} P<0 \cdot 05$.

$\dagger$ For details of dietary regimen, see p. 36.

$\ddagger$ For details of calculations, see p. 38 .

\section{RESULTS}

\section{Whole-body entry rate and oxidation}

The regression analysis results given in Tables 2 and 3 demonstrate that the mean changes in the magnitude of the various metabolite concentrations and SRA over the sampling period were always less than $10 \%$ in both fed and under-fed, shorn and unshorn groups of ewes, and there were no consistent trends with time. It was therefore possible to apply steady-state equations to the sampling means for each metabolite (Baird et al. 1983). Total NEFA entry rate was $41 \%$ higher in the fed shorn ewes compared with unshorn controls (Table 4). The mean glycerol entry rate was also $41 \%$ higher in the fed shorn group, although this value was not statistically significant from that recorded in unshorn animals. In all groups the measured total NEFA entry rate using $\left[1-{ }^{14} \mathrm{C}\right]$ palmitic acid was 3.4 times the value obtained using $\left[2-{ }^{3} \mathrm{H}\right]$ glycerol. There was no significant difference between fed shorn and unshorn animals in either the contribution of NEFA to $\mathrm{CO}_{2}$ production or in the fraction of total NEFA entry rate oxidized. However, NEFA oxidation rate was $58 \%$ higher in the shorn group. These differences in lipid metabolism between shorn and unshorn ewes were removed on under-feeding. This effect was because of a tendency for the entry rates of glycerol and NEFA to rise by 37 and $52 \%$ respectively in the unshorn ewes following under-feeding. However, there was very little change in either of these indices of lipid metabolism between the fed and under-fed shorn group.

A significantly greater whole-body $\mathrm{CO}_{2}$ entry rate was observed in fed shorn animals compared with unshorn controls (Table 5), which resulted in a $22 \%$ higher value for estimated whole-body heat production. This increase in heat production was accounted for by a similar rise in fat oxidation by the shorn group. Under-feeding resulted in a $30 \%$ decrease in $\mathrm{CO}_{2}$ entry rate and estimated heat production in both shorn and unshorn groups. However, there was little change in the rate of NEFA oxidation, with the result that the fraction of whole-body heat production accounted for by NEFA oxidation rose by 37 and $56 \%$ in shorn and unshorn ewes respectively compared with values obtained in the fed state. 
Table 6. Mean packed cell volume (PCV), arterial blood concentrations of haemoglobin $(\mathrm{Hb})$, oxygen and carbon dioxide, and plasma concentrations of glucose, lactate, non-esterified fatty acids (NEFA), 3-hydroxybutyrate $(3 H B)$ and glycerol in fed and under-fed shorn $(S)$ and unshorn (US) pregnant ewes $\dagger$

\begin{tabular}{|c|c|c|c|c|c|c|c|c|}
\hline & \multicolumn{3}{|c|}{ Fed } & \multicolumn{3}{|c|}{ Under-fed } & \multirow[b]{2}{*}{$\operatorname{SED}^{3}$} & \multirow[b]{2}{*}{ SED $^{4}$} \\
\hline & $\begin{array}{c}\text { S } \\
\text { Mean }\end{array}$ & $\begin{array}{c}\text { US } \\
\text { Mean }\end{array}$ & SED $^{1}$ & $\underset{\text { Mean }}{S}$ & $\begin{array}{c}\text { US } \\
\text { Mean }\end{array}$ & $\mathrm{SED}^{2}$ & & \\
\hline $\mathrm{PCV}$ & 29 & 25 & $2 \cdot 2$ & 27 & 25 & $2 \cdot 6$ & $1 \cdot 0$ & $3 \cdot 2$ \\
\hline $\mathrm{Hb}(\mathrm{g} / \mathrm{l})$ & $121^{* *}$ & 89 & 5 & $111^{*}$ & 89 & 6 & 6 & 2 \\
\hline $\mathrm{O}_{2}(\mathrm{mM})$ & $6 \cdot 80^{* *}$ & $5 \cdot 08$ & 0.23 & $6.23^{*}$ & $5 \cdot 06$ & 0.22 & 0.37 & 0.09 \\
\hline $\mathrm{CO}_{2}(\mathrm{mM})$ & $26 \cdot 97^{*}$ & $24 \cdot 49$ & 0.56 & 26.83 & 24.91 & 1.80 & $1 \cdot 10$ & $0 \cdot 73$ \\
\hline Glucose (mм) & $2.55^{a}$ & $2 \cdot 60^{\mathrm{a}}$ & 0.22 & $201^{c}$ & $1.34^{\circ}$ & 0.51 & $0 \cdot 12$ & 0.22 \\
\hline Lactate (mM) & 0.44 & 0.42 & 0.04 & 0.54 & 0.48 & 0.05 & 0.03 & 0.08 \\
\hline NEFA (mM) & $0.83^{a}$ & $0.73^{a}$ & 0.09 & $\mathrm{I} \cdot 45^{\mathrm{c}}$ & $1.61^{\mathrm{c}}$ & 0.28 & $0 \cdot 10$ & $0 \cdot 17$ \\
\hline $3 \mathrm{HB}(\mathrm{mm})$ & $0 \cdot 88^{a}$ & $0.57^{a}$ & 0.24 & $1.05^{\mathrm{e}}$ & $1.29^{\mathrm{c}}$ & 0.33 & 0.05 & 0.21 \\
\hline Glycerol (mM) & $0 \cdot 17^{a}$ & $0 \cdot 15^{\mathrm{a}}$ & 0.01 & $0.22^{b}$ & $0 \cdot 19^{\mathrm{b}}$ & 0.02 & $0 \cdot 01$ & 0.01 \\
\hline
\end{tabular}

SED, standard error of difference; $\operatorname{SED}^{1}, \mathrm{~S} v$. US, fed $n 5 ; \mathrm{SED}^{2}, \mathrm{~S} v$. US, under-fed, $n 4$; $\operatorname{SED}^{3}$, fed $v$. under-fed, $\mathrm{S}, n 4 ; \mathrm{SED}^{4}$, fed $v$. under-fed, US, $n 5$.

a,b,e Values in the same rows with different superscript letters were significantly different, as assessed by a paired $t$ test (fed $v$. under-fed): ${ }^{\mathrm{a}, \mathrm{b}} P<0.05,{ }^{\mathrm{a}, \mathrm{c}} P<0.01$.

Significant differences between means (S. v. US), assessed by a paired $t$ test: ${ }^{*} P<0.05,{ }^{*}{ }^{*} P<0.01$.

+ For details of dietary regimen, see p. 36.

\section{Plasma metabolites, hormone concentrations and blood gases}

There were no significant differences between shorn and unshorn ewes in the arterial plasma concentrations of glucose, lactate, NEFA, 3-hydroxybutyrate or glycerol in fed or underfed animals (Table 6). Shorn animals did exhibit significantly higher blood $\mathrm{CO}_{2}$ and oxygen concentrations. This latter change was associated with a significant increase in blood haemoglobin that was apparent in both fed and under-fed shorn ewes.

The response to under-feeding in terms of changes in the concentration of plasma metabolites was generally in the same direction in both shorn and unshorn groups, i.e. a decrease in plasma glucose concentration and a rise in the plasma concentrations of NEFA, 3-hydroxybutyrate and glycerol (Table 6). However, the magnitude of change in plasma glucose, NEFA and 3-hydroxybutyrate levels as a result of under-feeding was much greater in unshorn compared with shorn ewes. The decrease in plasma glucose concentration was $20 \%$ in the shorn group compared with $50 \%$ in unshorn animals, while the increases in plasma NEFA and 3-hydroxybutyrate concentrations on under-feeding were 121 and $126 \%$ respectively in the unshorn ewes compared with 75 and $19 \%$ in shorn ewes.

From Table 7 it can be observed that the arterial plasma concentrations of glucagon, $\mathrm{T}_{4}$ and $T_{3}$ were all significantly higher in the fed shorn ewes. This difference in thyroid hormone concentrations between shorn and unshorn groups was maintained on under-feeding. There was no difference in the plasma concentration of glucagon between the two groups on under-feeding because of a $57 \%$ increase in plasma glucagon concentration in the unshorn ewes. Under-feeding also caused a significant decrease in plasma insulin concentration in both groups, and this response was $50 \%$ greater in the unshorn group. These different responses in the plasma concentrations of insulin and glucagon to underfeeding between shorn and unshorn groups meant that the molar I: $G$ ratio decreased by $82 \%$ in unshorn ewes compared with $47 \%$ in shorn animals. There were no significant differences in the circulating levels of $\mathrm{GH}$, insulin or cortisol between the two groups of 
Table 7. Mean arterial plasma concentrations of growth hormone $(G H)$, insulin, glucagon, molar insulin: growth hormone ratio $(I: G H)$, molar insulin:glucagon ratio $(I: G)$, cortisol, thyroxine $\left(T_{4}\right)$ and triiodothyronine $\left(T_{3}\right)$ in fed and under-fed shorn $(S)$ and unshorn $(U S)$ pregnant ewes:

\begin{tabular}{|c|c|c|c|c|c|c|c|c|}
\hline & \multicolumn{3}{|c|}{ Fed } & \multicolumn{3}{|c|}{ Under-fed } & \multirow[b]{2}{*}{$\mathrm{SED}^{3}$} & \multirow[b]{2}{*}{$\operatorname{SED}^{4}$} \\
\hline & $\underset{\text { Mean }}{S}$ & $\begin{array}{c}\text { US } \\
\text { Mean }\end{array}$ & $\operatorname{SED}^{1}$ & $\begin{array}{c}S \\
\text { Mean }\end{array}$ & $\begin{array}{c}\text { US } \\
\text { Mean }\end{array}$ & SED $^{2}$ & & \\
\hline $\mathrm{GH}(\mathrm{ng} / \mathrm{ml})$ & 6.89 & 6.02 & $1 \cdot 50$ & $6 \cdot 85$ & $7 \cdot 52$ & 1.60 & 0.44 & 0.86 \\
\hline Insulin ( $\mathrm{ng} / \mathrm{ml})$ & $0 \cdot 20^{\mathrm{a}}$ & $0 \cdot 23^{a}$ & $0 \cdot 03$ & $0 \cdot 13^{b}$ & $0 \cdot 08^{\mathrm{b}}$ & 0.03 & 0.03 & $0 \cdot 04$ \\
\hline Glucagon $(\mathrm{ng} / \mathrm{ml})$ & $0 \cdot 10^{* *}$ & $0.07^{a}$ & 0.005 & $0 \cdot 12$ & $0 \cdot 11^{\mathrm{b}}$ & 0.02 & 0.02 & $0 \cdot 01$ \\
\hline I: GH & $0 \cdot 14$ & $0 \cdot 18$ & 0.03 & $0 \cdot 10$ & 0.07 & 0.05 & 0.09 & 0.06 \\
\hline $\mathrm{I}: \mathrm{G}$ & $1 \cdot 5^{*}$ & $2 \cdot 2^{a}$ & 02 & 0.8 & $0 \cdot 4^{b}$ & $0 \cdot 3$ & $0 \cdot 3$ & 0.5 \\
\hline Cortisol (ng/ml) & 16.9 & $9 \cdot 7$ & 60 & $20 \cdot 2$ & $18 \cdot 1$ & 9.7 & $5 \cdot 8$ & 6.9 \\
\hline$T_{4}(\mathrm{nM})$ & $82 \dagger$ & 66 & 6 & $84 * * *$ & 54 & 3 & 13 & 3 \\
\hline$T_{3}(n M)$ & $1 \cdot 35^{* a}$ & $1 \cdot 09^{\mathrm{a}}$ & 0.09 & $1 \cdot 00+b$ & $0.45^{b}$ & $0 \cdot 16$ & 0.12 & $0 \cdot 16$ \\
\hline
\end{tabular}

SED, standard error of difference; $\operatorname{SED}^{1}, \mathrm{~S} v$. US, fed, $n 5 ; \mathrm{SED}^{2}, \mathrm{~S} v$. US, under-fed, $n 4 ; \mathrm{SED}^{3}$, fed $v$. under-fed, $\mathrm{S}, n 4 ; \mathrm{SED}^{4}$, fed $v$. under-fed, US, $n 5$.

a.b Values in the same rows with different superscript letters were significantly different, as assessed by a paired $t$ test (fed $v$. under-fed): $P<0.05$.

Significant differences between means ( $\mathrm{S} v$. US), assessed by a paired $t$ test: $+P=0.06,{ }^{*} P<0.05$, ** $P<0.01, * * * P<0.001$.

$\ddagger$ For details of dietary regimen, see p. 36 .

animals, either in the fed or under-fed state. No significant changes in the circulating levels of $\mathrm{GH}$, cortisol and $\mathrm{T}_{4}$ were apparent in response to under-feeding in either shorn or unshorn ewes.

\section{DISCUSSION}

\section{Whole-body NEFA metabolism}

The present study demonstrates the important contribution made by NEFA towards oxidative metabolism during late pregnancy, since $38 \%$ of whole-body $\mathrm{CO}_{2}$ entry rate was derived from plasma NEFA in unshorn ewes when fed at an ME level sufficient to meet only $55 \%$ of daily requirements (Agricultural Research Council, 1980). This value increased to $57 \%$ when the feeding level was reduced by a further two-thirds. Shearing pregnant ewes 8 weeks before lambing, caused a $22 \%$ higher rate of whole-body heat production when measured between 4 and 1 weeks before lambing. In addition the shorn animals exhibited higher concentrations of blood gases, thereby confirming that they were making long-term metabolic adaptations to continuous cold exposure (Symonds et al. $1986 a, 1988 b$ ). These effects were associated with a $58 \%$ rise in the contribution of NEFA to total heat production, agreeing with our earlier results (Symonds et al. 1986a), made using indirect calorimetery, that shearing imposes a chronic increase in energy demand which is met by oxidizing maternal adipose tissues. This response was the result of 42 and $58 \%$ higher whole-body NEFA entry and oxidation rates respectively, compared with unshorn ewes at the same stage of pregnancy.

Undernutrition, induced by giving a diet only sufficient to provide $17 \%$ of the estimated daily ME requirement of the unshorn ewes, removed any significant differences in lipid metabolism observed between shorn and unshorn groups in the fed state. This effect was caused by the mean entry rates of glycerol and NEFA increasing by 37 and $52 \%$ respectively in the unshorn group. However, in the shorn group there was little change in 


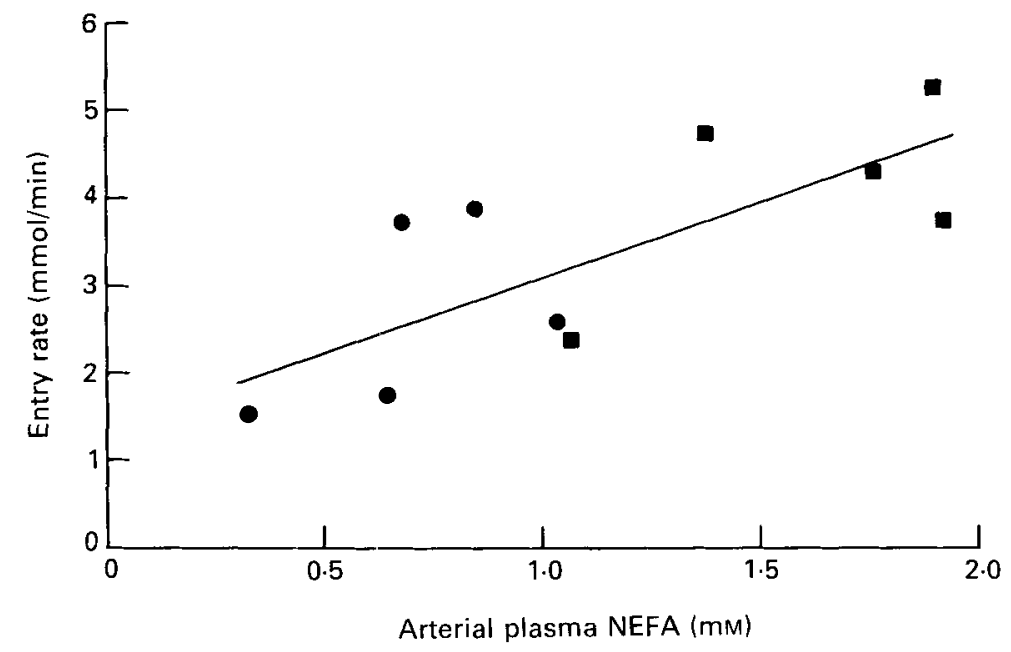

Fig. 1. Entry rate of non-esterified fatty acids (NEFA) in fed $(\boldsymbol{O})$ and under-fed $(\boldsymbol{\square})$ unshorn pregnant ewes;

$$
y=1 \cdot 7 x+1.34\left(r^{2} 0 \cdot 48 ; P<0 \cdot 05\right),
$$

where $x$ is the arterial plasma concentration of NEFA (mM) and $y$ is the entry rate $(\mathrm{mmol} / \mathrm{min})$.

these measurements of lipid metabolism, and this indicates that under-feeding had a greater stimulatory effect on lipolysis in unshorn compared with shorn ewes. This proposal is confirmed by the changes recorded in circulating metabolites in shorn and unshorn groups between the fed and under-fed nutritional states. In the unshorn ewes the mean plasma concentrations of NEFA and 3-hydroxybutyrate increased by 121 and $126 \%$ respectively on under-feeding, compared with 75 and $19 \%$ in the shorn group. Also the plasma glucose concentration decreased by $50 \%$ during under-feeding in unshorn animals compared with $20 \%$ in shorn animals.

Under-feeding caused a $30 \%$ fall in whole-body $\mathrm{CO}_{2}$ entry rate and estimated total heat production in both shorn and unshorn groups. There was little change in the whole-body rates of fat oxidation in both groups of ewes but, due to the decrease in total heat production, the contribution of NEFA to total heat production rose to 82 and $75 \%$ respectively in shorn and unshorn animals. This is the value one may expect to obtain when an animal is relying primarily on fat reserves as an energy source (Blaxter, 1962).

\section{NEFA and glycerol entry rates}

The results from the present study clearly demonstrate that both the total NEFA entry and oxidation rates were significantly higher in shorn animals, although there was no difference in the circulating NEFA levels between the two groups of ewes. This confirms the proposal that the normal relation between plasma concentration and turnover rate of NEFA is altered following exposure to a cold environment for an extended period of time (Graham \& Phillips, 1981). A significant relation between the concentration of NEFA in arterial plasma and both the total NEFA entry rate (Fig. 1) and fraction of $\mathrm{CO}_{2}$ produced from NEFA (Fig. 2) was observed in the fed and under-fed unshorn ewes. However, no such relation was apparent in the shorn animals, which is not surprising since these animals exhibited significantly higher entry and oxidation rates of NEFA than unshorn ewes in the fed state, but there was no difference in the arterial plasma NEFA concentration. In shorn ewes there was a positive relation between the fraction of $\mathrm{CO}_{2}$ produced from NEFA and 


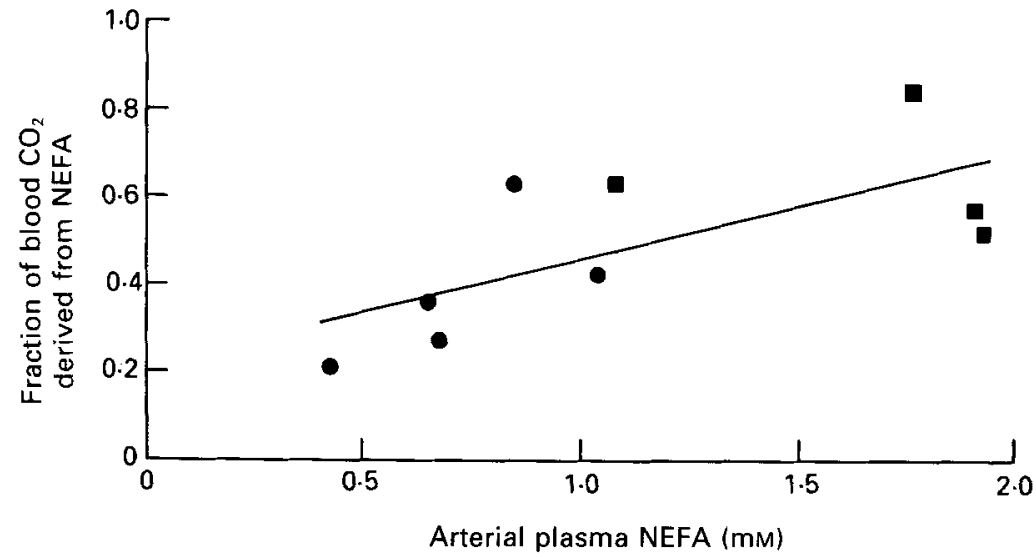

Fig. 2. Fraction of blood carbon dioxide derived from non-esterified fatty acids (NEFA) oxidation in fed ( $O)$ and under-fed (ם) unshorn pregnant ewes;

$$
y=0.24 x+0.22\left(r^{2} 0.39 ; P<0.05\right)
$$

where $x$ is the arterial plasma concentration of NEFA (mM) and $y$ is the proportion of blood $\mathrm{CO}_{2}$ derived from the oxidation of NEFA.

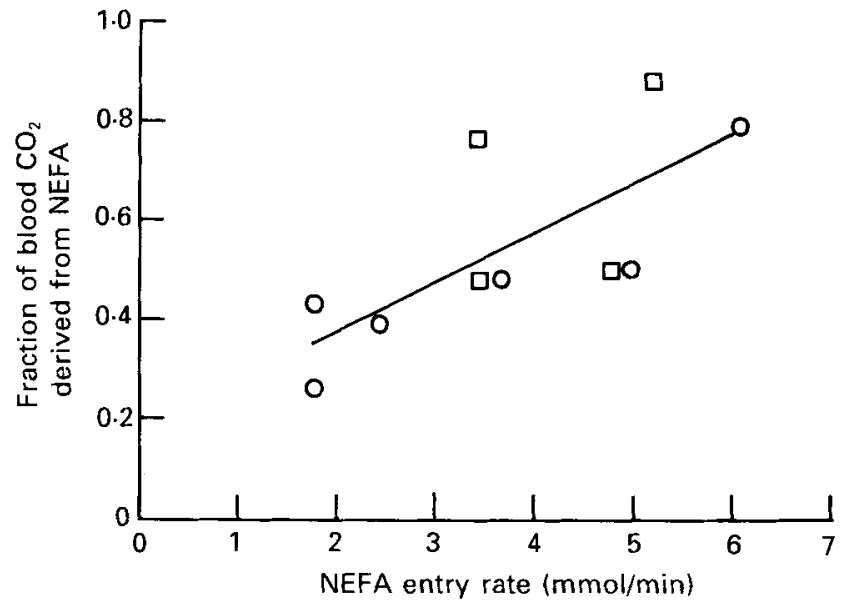

Fig. 3. Fraction of blood carbon dioxide derived from non-esterified fatty acid (NEFA) oxidation in fed $(O)$ and under-fed $(\square)$ shorn pregnant ewes;

$$
y=0.096 x+0.19\left(r^{2} 0.47 ; P<0.05\right),
$$

where $x$ is the entry rate of NEFA ( $\mathrm{mmol} / \mathrm{min}$ ) and $y$ is the proportion of blood $\mathrm{CO}_{2}$ derived from the oxidation of NEFA.

the total NEFA entry rate (Fig. 3). This indicates that the plasma NEFA concentration is not increased in winter-shorn pregnant ewes, because the higher lipolytic rate is associated with a significant rise in the rate of NEFA for oxidation.

The method adopted to measure total NEFA entry and oxidation rates in the present study was based on the assumption that the tracer NEFA $\left[1-{ }^{14} \mathrm{C}\right]$ palmitic acid was representative of total NEFA. In the arterial plasma of sheep the molar proportion of palmitic acid is $20 \%$ and this value is unchanged by pregnancy, starvation (Pethick et al. 
1983) or cold exposure (Thompson et al. 1975). There are several reports which have demonstrated that the total entry rate estimated from the use of $\left[1-{ }^{14} \mathrm{C}\right]$ palmitic acid gives a similar value to that obtained using repeated measurements with $\left[{ }^{14} \mathrm{C}\right]$ palmitic, $\left[{ }^{14} \mathrm{C}\right] \mathrm{stearic}$ and $\left[{ }^{14} \mathrm{C}\right]$ oleic acids in adult ruminants (Annison et al. 1968; Leng \& West, 1969; Pethick et al. 1983). It has also been established that individual NEFA are equally susceptible to oxidation (Pethick et al. 1983) and it is therefore possible to calculate the total NEFA oxidation rate using $\left[{ }^{14} \mathrm{C}\right]$ palmitic acid.

The values in the present study of 0.043 and $0.033 \mathrm{mmol} / \mathrm{min}$ per $\mathrm{kg}$ body-weight for total NEFA entry rate for shorn and unshorn fed ewes respectively are five to six times higher than those measured by Pethick et al. (1983). However, in the latter study no information was given with respect to the stage of pregnancy at which measurements were made, the exact food intake of the small number (i.e. three) of fed ewes studied, lamb birth weight or fetal numbers. These authors also failed to indicate if steady-state conditions were established during the sampling period of $1-{ }^{14} \mathrm{C}$-labelled NEFA infusion, since they only stated that 'the SRA of plasma NEFA remained fairly constant'. These factors make any direct comparison of NEFA entry rates between that and the present study difficult to interpret. It is, however, worth pointing out that in our earlier study (Symonds et al. 1986a) the rate of fat oxidation in unshorn ewes (measured by indirect calorimetry), of the same breed as that used in the present study and consuming a similar ME, was double the rate measured by Pethick et al. (1983). This indicates that both shorn and unshorn ewes could be expected to exhibit a higher rate of lipolysis than that measured by Pethick et al. (1983), and is in accord with our previous work in which all ewes were shown to be mobilizing body tissue (Symonds et al. 1986a).

The values for total NEFA entry rate in the present study are similar to those measured in goats between weeks 29 and 36 of lactation following a $24 \mathrm{~h}$ starvation (Annison et al. 1968). In the present study the total NEFA entry rate measured using $\left[1-{ }^{14} \mathrm{C}\right]$ palmitic acid was three times that estimated from infusing $\left[{ }^{14} \mathrm{C}\right]$ palmitic, $\left[{ }^{14} \mathrm{C}\right]$ stearic and $\left[{ }^{14} \mathrm{C}\right]$ oleic acids into different goats. However, the respiratory quotient across the mammary gland of the animal into which $\left[1-{ }^{14} \mathrm{C}\right]$ palmitic acid was infused was $20 \%$ lower than in other goats. Consequently the rate of fat oxidation across this tissue would have been two to three times higher, thereby explaining why the rate of lipolysis was so much higher in this particular lactating goat.

The mean values for glycerol entry rate in shorn and unshorn ewes in the present study were between 0.0047 and $0.0033 \mathrm{mmol} / \mathrm{min}$ per $\mathrm{kg}$ body-weight. These values are in the same range as other published results $(0.0033-0.0077 \mathrm{mmol} / \mathrm{min}$ per $\mathrm{kg}$ body-weight) made in twin pregnant sheep over the final 3 weeks of pregnancy, which had either been fed or starved for a 3-5 d period (Bergman, 1968; Bergman et al. 1968; Ranaweera et al. 1981).

\section{Incomplete breakdown of adipose tissue triglycerides}

In both shorn and unshorn groups of ewes the total NEFA entry rate as measured using $\left[1-{ }^{14} \mathrm{C}\right]$ palmitic acid was 3.4 times greater than that calculated from multiplying the glycerol entry rate by 3 (assuming the release of $1 \mathrm{~mol}$ glycerol to $3 \mathrm{~mol}$ NEFA) and, therefore, the mean ratio of NEFA:glycerol release was $10: 1$ in both shorn and unshorn animals, irrespective of nutritional state. This effect is unlikely to be the result of inaccurate measurements of total NEFA entry rates because, as discussed previously, they are in agreement with other studies made in ruminant animals which may be expected to be mobilizing significant quantities of adipose tissue. Furthermore, Symonds (1986) demonstrated in maintenance-fed adult wethers that the simultaneous use of $\left[1{ }^{14} \mathrm{C}\right]$ palmitic acid and $\left[2-{ }^{3} \mathrm{H}\right]$ glycerol both gave very similar values for total NEFA entry rate. These results indicate that lipolysis occurred in both shorn and unshorn ewes via the incomplete 
breakdown of adipose tissue triglycerides, i.e. triglycerides were hydrolysed to diglycerides or monoglycerol, or both. This has previously been suggested as an explanation for the relatively small rise in plasma glycerol concentration following a $4 \mathrm{~d}$ period of starvation of sheep over the final 3 weeks of pregnancy (Ranaweera et al. 1981). Furthermore, both the acute (Bergman, 1968; Sidu \& Emery, 1973) and chronic stimulatory effect of noradrenaline on lipolysis in ruminants (Symonds et al. 1986 b) is thought to be mediated via the incomplete breakdown of adipose tissue triglycerides. This effect is not only confined to in vivo studies but has also been observed in vitro using adipose tissue from lactating cows (Yang \& Baldwin, 1973).

The process of incomplete breakdown of adipose tissue triglycerides may be mediated via a stimulation of the activity of hormone-sensitive lipase which catalyzes the initial cleavage of triacylglycerol to diacylglycerol. This is normally the rate-limiting step in triglyceride hydrolysis (Vernon, 1980), but an increased flux through this step may result in the activity of diacylglycerol lipase or monoglycerol lipase, or both, limiting the lipolytic rate. The pregnant ewe may benefit from the incomplete breakdown of adipose tissue triglycerides, as this will reduce any requirement for glycerol in adipose tissue triglyceride synthesis to a minimum at a time when lipolytic activity is high (lliou \& Demarne, 1987). Therefore, triglyceride turnover can occur without a further requirement for glycerol. This in turn will result in a reduction in the use of glucose for glycerol-3-phosphate synthesis, thereby increasing the availability of glucose for other purposes, such as glucose supply to the developing fetus.

The previously mentioned results are in direct contrast to the only other report in which the simultaneous use of radio-labelled glycerol and palmitic acid has been made in underfed single bearing ewes during the final third of pregnancy (Wilson, 1984), compared with mainly twin-bearing ewes in the present study. The work by Wilson (1984) has only been reported in abstract form, to which some of the criticisms made previously with respect to Pethick et al. (1983) also apply. It is also unlikely that a significant amount of reesterification of NEFA will occur at this stage of pregnancy, since in subcutaneous adipose tissue the rate of glycerol synthesis from glucose is significantly reduced (Vernon et al. 1981). Glucose also fails to inhibit NEFA release in vitro from bovine subcutaneous adipose tissue taken during late pregnancy or early lactation (Metz \& van den Bergh, 1972), thereby indicating that the activities of enzymes involved in the re-esterification pathway are low when lipolysis is high.

Wilson (1984) suggested that re-esterification would account for $35 \%$ of the glucose entry rate, which the under-fed pregnant ewe is likely to have difficulty in meeting, because other studies by Wilson et al. (1983) indicated that 55-66\% of whole-body glucose entry rate is oxidized, with the remainder being used for non-essential amino acid synthesis. This observation, together with the high demand for glucose of the fetus and utero-placental unit (Oddy et al. 1985), suggests that little glucose would be available for the reesterification of NEFA in adipose tissue. It is therefore more likely that the incomplete breakdown of adipose tissue triglycerides occurs in the late pregnant ewe which is mobilizing significant quantities of body fat depots. This represents a biochemical mechanism by which ruminants in negative energy balance can maximize their lipolytic rate when the glucose requirement for homeorrhetic purposes, such as fetal development or milk production, is maximal. Consequently its availability for triglyceride re-esterification is minimal.

\section{Hormonal regulation of lipid metabolism}

The higher NEFA entry rate measured in fed shorn animals is unlikely to be mediated via insulin or $\mathrm{GH}$, because there was no difference in either the circulating concentration or molar ratio of these hormones between shorn and unshorn groups. Sympathetic activity is 
likely to be higher in shorn compared with unshorn ewes (Symonds \& Lomax, 1988). It is, therefore, possible that the sympathetic nervous system, via the lipolytic effect of noradrenaline, may play an important role in the control of NEFA homeostasis in the shorn ewe. The increased rates of lipolysis and NEFA oxidation in shorn ewes could also be influenced by the higher plasma concentrations of $T_{3}$ and $T_{4}$, because in the nonruminant, thyroid hormones have a synergistic effect with catecholamines in stimulating lipolysis and heat production (Landsberg, 1978).

The primary endocrine response to under-feeding in shorn and unshorn ewes was a decrease in the plasma concentration of insulin, with this effect being $50 \%$ greater in the unshorn group. A $57 \%$ increase in plasma glucagon concentration was also measured in the unshorn group, with the result that the molar I: $\mathrm{G}$ ratio decreased by $87 \%$, compared with $47 \%$ in shorn ewes. This change in $I: G$ ratio as a result of under-feeding is in accord with similar studies in lactating ewes (Gow et al. 1981). Glucagon may provide the hormonal stimulus for lipolysis in under-fed unshorn ewes, because it has been suggested that the action of glucagon on adipose tissue is lipolytic when insulin concentrations are low (Brockman et al. 1975).

It is concluded that when the pregnant ewe is fed on a diet which provides no more than half the required ME for late pregnancy, then mobilization of body fat depots occurs via the incomplete breakdown of adipose tissue triglycerides. This effect is greater in the fed shorn pregnant ewe which, as a result of the endocrine and metabolic adaptations to chronic cold exposure, exhibits higher rates of NEFA mobilization and oxidation compared with unshorn sheep without any difference in the plasma concentration of NEFA.

M.E.S. acknowledges the support of a MAFF studentship; this work was also funded by an AFRC research grant.

\section{REFERENCES}

Agricultural Research Council (1980). Requirements for energy. In The Nutrient Requirements of Ruminant Livestock, pp. 115-119. Slough: Commonwealth Agricultural Bureaux.

Annison, E. F., Linzell, J. L. \& West, C. E. (1968). Mammary and whole animal metabolism of glucose and fatty acids in fasting lactating goats. Journal of Physiology 197, 445-459.

Baird, G. D., van der Walt, J. G. \& Bergman, E. N. (1983). Whole-body metabolism of glucose and lactate in productive sheep and cows. British Journal of Nutrition 50, 249-265.

Bell, A. W. \& Thompson, G. E. (1979). Free fatty acid oxidation in bovine muscle in vivo: effects of cold exposure and feeding. American Journal of Physiology 237, E309-E315.

Bergman, E. N. (1968). Glycerol turnover in the nonpregnant and ketotic pregnant sheep. American Journal of Physiology 215, 865-873.

Bergman, E. N., Starr, D. J. \& Reulein, S. S. (1968). Glycerol metabolism and gluconeogenesis in the normal and hypoglycemic sheep. American Journal of Physiology 215, 874-880.

Blaxter, K. L. (1962). The fasting metabolism of adult wether sheep. British Journal of Nutrition 16, 615-626.

Brockman, R. P., Bergman, E. N., Joo, P. K. \& Manns, J. G. (1975). Effects of glucagon and insulin on net hepatic metabolism of glucose precursors in sheep. American Journal of Physiology 229, 1344-1350.

Gow, C. B., McDowell, G. H. \& Annison, E. F. (1981). Control of gluconeogenesis in the lactating sheep. Australian Journal of Biological Sciences 34, 469-478.

Graham, A. D. \& Phillips, G. D. (1981). Plasma glucose, lactate and free fatty acid responses to adrenaline in warm- and cold-acclimated sheep. Canadian Journal of Animal Science 61, 919924.

Hammerstedt, R. H. (1973). The use of dowex-1-borate to separate ${ }^{3} \mathrm{HOH}$ from $2-{ }^{3} \mathrm{H}$-glucose. Analytical Biochemistry 56, 292-293.

Iliou, J. P. \& Demarne, Y. (1987). Evolution of the sensitivity of isolated adipocytes of ewes to the lipolytic effects of different stimuli during pregnancy and lactation. International Journal of Biochemistry 19, $253-258$.

Landsberg, L. (1978). Catecholamines and the sympathoadrenal system. In The Thyroid-A Fundamental and Clinical Text, pp. 791-799 [S. C. Werner and S. H. Ingbar, editors]. New York: Harper and Row.

Leng, R. A. \& West, C. E. (1969). Contribution of acetate, butyrate, palmitate, stearate and oleate to ketone body synthesis in sheep. Research in Veterinary Science 10, $57-63$. 
Lindsay, D. B. \& Pethick, D. W. (1983). Metabolic disorders. In Dynamic Biochemistry of Animal Production, pp. 453 456 [P. M. Riis, editor]. Amsterdam: Elsevier.

Metz, S. H. M. \& van den Bergh, S. G. (1972). Effects of volatile fatty acids, ketone bodies, glucose and insulin on lipolysis in bovine adipose tissue. FEBS Letters 21, 203-206.

Oddy, V. H., Gooden, J. M., Hough, G. H., Teleni, E. \& Annison, E. F. (1985). Partitioning of nutrients in Merino ewes. 2. Glucose utilization by skeletal muscle, the pregnant uterus and the lactating mammary gland in relation to whole body glucose utilization. Australian Journal of Biological Sciences 38, 95-108.

Pethick, D. W., Lindsay, D. B., Barker, P. J. \& Northrop, A. J. (1983). The metabolism of circulating nonesterified fatty acids by the whole animal, hind-limb muscle and uterus of pregnant sheep. British Journal of Nutrition 49, 129-143.

Ranaweera, A., Ford, E. J. H. \& Evans, J. (1981). Gluconeogenesis from glycerol by ketonic sheep pregnant with twins. Research in Veterinary Science 30, 303-308.

Sidu, K. S. \& Emergy, R. S. (1973). Blood fatty acids and glycerol response to diet and norepinephrine. Journal of Dairy Science 56, 258-260.

Symonds, M. E. (1986). Energy metabolism in the shorn and unshorn pregnant ewe. PhD Thesis, University of Reading.

Symonds, M. E., Bryant, M. J. \& Lomax, M. A. (1986a). The effect of shearing on the energy metabolism of the pregnant ewe. British Joumal of Nutrition 56, 635-643.

Symonds, M. E., Bryant, M. J. \& Lomax, M. A. (1988a). Metabolic adaptation during pregnancy in winter-shorn sheep. Journal of Agricultural Science, Cambridge 111, 137-145.

Symonds, M. E., Bryant, M. J., Shepherd, D. A. \& Lomax, M. A. (1988b). Glucose metabolism in shorn and unshorn pregnant sheep. British Journal of Nutrition 60, 249-263.

Symonds, M. E., Hannah, M. J., Kirkman, R. J. \& Lomax, M. A. (1986b). The effect of intravenous noradrenaline infusion on lipolysis in adult sheep. Proceedings of the Nutrition Society 45, 79A.

Symonds, M. E. \& Lomax, M. A. (1988). Effect of short-term intravenous infusion of noradrenaline on energy metabolism in shorn and unshorn pregnant sheep. Research in Veterinary Science 46, 58-61.

Thompson, G. E., Gardner, J. W. \& Bell, A. W. (1975). The oxygen consumption, fatty acid and glycerol uptake of the liver in fed and fasted sheep during cold exposure. Quarterly Journal of Experimental Physiology 60 , $107-121$.

Vernon, R. G. (1980). Lipid metabolism in the adipose tissue of ruminant animals. Progress in Lipid Research 19, 23-106.

Vernon, R. G., Clegg, R. A. \& Flint, D. J. (1981). Metabolism of sheep adipose tissue during pregnancy and lactation. Biochemical Journal 200, 307-314.

Wieland, O. (1974). Glycerol UV-method. In Methods of Enzymatic Analysis, pp. 1404-1409 [H. U. Bergmeyer and $\mathrm{K}$. Gawehn, editors]. Weinheim: Verlag Chemie.

Wilson, S. (1984). The metabolism of fatty acids in undernourished ewes. Canadian Journal of Animal Science 64, Suppl., 246-247, Abstr.

Wilson, S., MacRae, J. C. \& Buttery, P. J. (1983). Glucose production and utilization in non-pregnant, pregnant and lactating ewes. British Journal of Nutrition 50, 303-316.

Yang, Y. T. \& Baldwin, R. L. (1973). Lipolysis in isolated cow adipose cells. Journal of Dairy Science 56, 366-374. 